\title{
An Investigation Into The Drag Increase on Roughen Surface due to Marine Fouling Growth
}

\author{
A. K. Yusim ${ }^{1}$, and I. K. A. P. Utama²
}

\begin{abstract}
Marine biofouling attached to underwater ship hull has caused problems for many years to ship operators. It has been reported to increase the total drag thus can reduce the speed of ship and disturb the overall operation of marine vehicles. Changes laminar to turbulent flow becomes fast when passing through rough ships surface. The current study models the growth of marine fouling for one year periods basis on general cargo vessel. The methods have been used in this studied was model scale $1: 53$. The use of smooth model is also included in order to analyses the difference between the two conditions. Two models of the hull roughness are regular and irregular roughness. The modeling of roughness using sand with a specific size and have been scaled. The results show that an increase in skin friction drag of about $41 \%$ per year for biofouling spread not evenly at wetted surface area (WSA).
\end{abstract}

Keywords — towing tank, biofouling, sand, drag.

Abstrak-Biofouling yang menempel pada lambung kapal merupakan permasalahan yang muncul ketika kapal mulai beroperasi. Penempelan ini akan menimbulkan kekasaran dan menambah tebal pada permukaan kapal yang tercelupdalam air laut. Perubahan aliran laminar ke turbulen menjadi cepat ketika melewati permukaan kapal yang kasar. Penelitian ini memodelkan pertumbuhan biofouling pada periode satu tahun untuk kapal general cargo. Metode yang digunakan dalam penelitian ini adalah pengujian model fisik dengan skala 1 : 53. Penggunaan smooth model juga harus disertakan untuk analisis perbedaan antara dua kondisi kekasaran lambung model. Dua kondisi kekasaran pada lambung model yaitu regular roughness dan irregular roughness. Pemodelan kekasaran akibat biofouling ini menggunakan pasir dengan ukuran tertentu dan sudah diskalakan. Hasil dari pengujian menunjukkan bahwa pertumbuhan biofouling selama kapal beroperasi dalam 1 tahun menimbulkan peningkatan hambatan gesek sebesar $41 \%$ untuk kapal dengan biofuling tidak merata pada luas permukaan basah.

Kata Kunci-towing tank, biofouling, sand, drag.

\section{INTRODUCTION}

G lobal warming due to increased carbon emissions become a hot issue in the last 10 years. All industry sectors including shipbuilding industry accounts for a large proportion of this increase in carbon emissions. Attachment of biofouling on ship hulls physically increase the volume (displacement) and the flow pattern when the ship sailed.

Marine biofouling has been found to cause disaster to ship operation for many years. Intensive growth of biofouling on underwater ship hull for one year operations has been reported to reduce the speed of ship up to $20 \%$ [1] and the fuel consumption for one year operations increases about $50 \%$ [2].

Biofouling growth is not linear or can be difficult to predict because it is influenced by many factors. For example on the type of animal (barnacles), the growth rate is determined by the level of food. Based on the period of growth, biofouling rapid growth in the initial period (first 1.5 months) and slowed in subsequent periods [3]. Conditions biofouling uneven roughness for the area observed (corresponding in TABLE 1 ) requires making the appropriate model is irregular roughness. Calculations for irregular roughness models use equations of PrandtlSchlichting for local skin friction drag coefficient $C_{f}$ roughness of each region is different [4], i.e.:

$C_{f}=\left[\left(2.87+1.58 \log _{10}\left(\frac{x}{K_{S}}\right)\right)\right]^{-2.5}$

\footnotetext{
${ }^{1}$ A. K. Yusim, is with Department of Mechanical Engineering, FT, Universitas Jember, Jember, 68121, Indonesia. Email:adiyusim.teknik@unej.ac.id
}

where:

$\mathrm{x}$ is length of each area different roughness (m),

Ks is height of roughness (m).

Another model in this research is regular roughness. This model is conditions biofouling even roughness along a ship. Prandtl-Schlichting formulated differently on this condition [4], that:

$C_{F}=\left[\left(1.894+1.62 \log _{10}\left(\frac{L}{K_{S}}\right)\right)\right]^{-2.5}$

$\mathrm{C}_{\mathrm{F}}$ is total skin friction drag coefficient,

$\mathrm{L}$ is length of ship model (m).

Many efforts have been done in order to anticipate the problem such as by conducting regular docking as a regulation of class others, e.g. [1] attempted to understand the growth of marine biofouling and its effect on the reduction of speed of a vessel. Similar work is carried out in the current work using a ship model and tested experimentally at ITS towing tank.

Any surface placed in water, gradually becomes home of biofouling (bacteria, algae, invertebrates). The ship performance has particularly vicious effect from this biofouling [1]. Specifically, the buildup of biofouling on ships pose a significant problem. In some cases, the structure of the hull and propulsion systems could be damaged [5]

Drag is a force that disrupting to the speed of a ship so as to the presence of these constraints it takes a force of thrust for propelling vessels. A ship will face several drag while sailing as a consequence of the interaction between ship with the environment in the sea. These drags include

${ }^{2}$ I. K. A. P. Utama is with Department of Naval Architecture and Shipbuilding, Institut Teknologi Sepuluh Nopember, Surabaya, 60111, Indonesia. E-mail:kutama@na.its.ac.id 
wave, air, and friction drag. In addition, there are other drags, among others, drag due to biofouling and corrosion on hull [6]. Total drag of a ship [6] may be calculated as follows:

$R_{T}=0.5 \times \rho \times C_{T} \times S \times V^{2}$

where $\rho$ is density of salt water, $C_{T}$ is total drag coefficient, $\mathrm{S}$ is wetted surface area, and $\mathrm{V}$ is velocity of ship.

Based on ITTC 1978 [6], the total drag coefficient is expressed as:

$C_{T}=C_{F}+C_{R}$

where:

$\mathrm{C}_{\mathrm{F}}$ is frictional drag coefficient $=0.075 /(\log 10 \mathrm{Re}-2)^{2}$,

$\mathrm{C}_{\mathrm{R}}$ is residual drag, which is dominated by wave drag.

A ship model, which has been scaled from a ship, can be used to evaluate the hydrodynamic characteristics of a ship in towing tank. A towing tank can produce outputs of total drag $\left(\mathrm{R}_{\mathrm{T}}\right)$ and its components can be derived from the application of $\mathrm{C}_{\mathrm{F}}$ (obtained from ITTC-1957 correlation line) to give frictional drag $\left(R_{F}\right)$ and wave drag $\left(R_{W}\right)$. Furthermore, the use of towing tank gives useful information of the flow movement around the ship.

Calculation of total resistance to roughened surface model is different from the usual model (standard). There is a roughness allowance $\left(\Delta \mathrm{C}_{\mathrm{F}}\right)$ obtained from the new $\mathrm{C}_{\mathrm{F}}$ $\left(\mathrm{C}_{\mathrm{T}}\right.$ of the roughen model $\left.-\mathrm{C}_{\mathrm{R}}\right) . \mathrm{C}_{\mathrm{R}}$ assumptions are the same for both models because of the similarity of geometry.

Studies on the effect of roughness due to biofouling against obstacles ships have been done earlier through experimentation by [7], [8], and [9], then economic studies by [10] about the overall economic impact of fouling on the hull.

The spread of biofouling which inflicting violence along the hull has a thickness that is different depending on the location. Thicker boundary layer near the bow and stern than to be thinner on the hull. This roughness affects the local flow velocity is high. To model ships, violence can cause early transition from laminar to turbulent flow [11]. Biofouling method for distributing data processing with the help of visual picture. Field observations and these photos will show the thickness of the locations that have been grouped (bottom, bow, stern and side hull) [9].

Problem of this research is to predict how big the ship total resistance $\left(\mathrm{R}_{\mathrm{T}}\right)$, which occurs when the biofouling arise after the vessel to operate for one year and determine the roughness factor $\left(\Delta \mathrm{C}_{\mathrm{F}}\right)$ after biofouling arise after the vessel to operate for one year. The difficulty in this study is how to roughen surface of the hull standard model and media (things of roughness). From previous research there are several options sand and sand paper. From the literature suitable for this research is to use sand. The background of sand as a representation election biofouling is due to the sand surface allows observation of a very clear distinction in the boundary layer. Roughness of sand is a well-known and highly relevant in relation to the surface of the hull [8].

\section{METHOD}

The investigation may be carried as using the following stages:

\section{A. Physical Modelling}

The ship model used in this study is the general cargo. The models are made from woods (triplex) in order to obtain appropriate displacement as scaled from full ship mode in accordance with Froude law of similarity. Models made in Hydrodynamics Laboratory of the Department of Naval Architecture ITS. Model made per station which is connected by means of waterproof adhesive to form a strong and rigid blocks. Steps of physical modelling are shown in Figure 1. In short, the physical modelling can be divided into six different steps:

1. Preparing materials and tools, among others: ruler, cutter, putty knife, grinding machine, lines plan print out, triplex, putty, $\mathrm{G}$ glue, resin, fiberglass mat, and spray paint.

2. Cutting paper and triplex based on lines plan.

3. Assembling of triplex.

4. Peel attachment model using triplex.

5. Puttying for outer region and fiber for inner region.

6. Coating; base coat and final coat.

Model weight is $10.1 \mathrm{~kg}$ and model displacement mass $64.3 \mathrm{~kg}$. Thus, requiring a ballast of $54.2 \mathrm{~kg}$.

\section{B. Survey}

Survey to collect some vessel, facing marine biofouling growth on its hull was carried out at PT. Dok Perkapalan Surabaya (DPS). One example of a roro ferry was then chosen for further investigation. A survey data covering thickness and roughness biofouling attached along the hull ship. Observations biofouling on ship hulls only at the time of the survey only. Assuming the ships operated for one year in accordance with the explanation shipowner. Surveys are not conducted periodically due to limited research time. The results of survey are as follows TABLE 1. Under these conditions, need to be made physical models with sand thickness varying for each region shown in TABLE 2.

\section{Model Test}

The size of the model adapts to the dimensions of experiment tank. So that, in testing does not pose additional drag caused by a wall effect. Main dimensions of the tank are $50 \mathrm{~m}$ of length, $3 \mathrm{~m}$ of width, $2 \mathrm{~m}$ of depth, and $1.8 \mathrm{~m}$ of draught, $0.8-4 \mathrm{~m} / \mathrm{s}$ is carriage speed, until they reached the model scale is 1/53 of a ship actually. Principal particular of the vessel is given in Table 3.

A set of model test consist of 3 treatments of model, namely smooth hull, regular roughness, and irregular roughness was further carried out. Condition 3 models have the same WSA shown in Figure 2. Smooth hull is standard model in towing tank. Regular roughness is roughness evenly along model test highly draught. Sand sticking to the surface of the model with the help of paint. Sand sticking evenly on the surface of the model with the aid of wire mesh are presented in Figure 3. Ks value for regular roughness model is $0.337 \times 10^{-3} \mathrm{~m}$. While, irregular roughness is roughness evenly along model test according survey results in PT. (DPS). Especially for irregular roughness model, be simplified as shown in Figure 4. Sand diameter size on this model is shown TABLE 2. Cross section of sand grains stick to the model of irregular roughness shown in Figure 5. 


\section{Resistance Evaluation}

Evaluation of the resistance component was made into the breakdown of its component, but the analysis is based only on the total resistance.

\section{RESULTS AND DISCUSSION}

Model experiments and analyses performed according to the Froude method, the total resistance $\left(\mathrm{R}_{\mathrm{T}}\right)$ is divided into frictional resistance $\left(\mathrm{R}_{\mathrm{F}}\right)$ and residual resistance $\left(\mathrm{R}_{\mathrm{R}}\right)$. Model test at Froude number (Fr) 0.16-0.29.

\section{A. Experimental Investigation}

Resistance testing procedures started by giving ballast in the model in order to the position of water according to the water line (even keel). Furthermore, installation of models that is put model in the position of the centerline. Furthermore, the model is mounted on a hook (not changing the loaded position). Metal profiles fitted to the trains by using a holder. Model and load cell with a rope tied (tied up so the model can't be separated when pulled). Expenses mounted to the load cell by using a rope (for calibration). A set of model test consist of 3 treatments of model, namely smooth hull, regular roughness, and irregular roughness was further carried out.

In testing this model will get the value of $R_{T}$ in kilograms were then taken to the unit newton with multiplied by the earth's gravity $\left(9.8 \mathrm{~m} / \mathrm{s}^{2}\right)$. By using the Froude approach (the first scientist to introduce the details of the total resistance of ship models) resistance component can be determined by the equation:

$$
R_{T M}=R_{F M}+R_{R M}
$$

with:

$\mathrm{R}_{\mathrm{TM}}=$ Total resistance from model experiment,

$\mathrm{R}_{\mathrm{FM}}=$ Frictional resistance,

$\mathrm{R}_{\mathrm{RM}}=$ Residuary resistance.

Furthermore, $\mathrm{R}_{\mathrm{RM}}$ is used as extrapolation to obtain a total resistance of vessels ( $R_{R M}$ same with $\left.R_{R K}\right)$.

Data on the calculation of total resistance presented in Table 4.

\section{B. Discussions}

In the resistance tests, the ship model is towed by carriage at various speeds and the total longitudinal force acting on the model is measured by load cell. Turbulent stimulators are present at the bow of model $(95 \% \mathrm{~L}$ from aft) in order to simulate transition from laminar to turbulent boundary layer [12].

Results of the experimental work are calculated based on Froude method and shown in Figure 6, which describe the correlation of resistance against speed ship. The results of the resistance test analyses concerning the total drag increase caused a marine growth in one year periods. This drag an increase of $47 \%$ (irregular roughness) and $37 \%$ (regular roughness) in service speed. From this result, the difference between regular and irregular roughness are $8 \%$. Thus, the final result of drag increase (average) caused marine biofouling is $42 \%$.

TABLE 5 showed a comparative value of $\mathrm{C}_{\mathrm{F}}$ from two different methods, namely experiment and empirical formula from Prandtl-Schlichting. $C_{F}$ value of the empirical formula (models of regular and irregular roughness) is fixed for different Froude numbers. The results show that an increase in skin friction drag of about $41 \%$ per year for biofouling spread not evenly at WSA in service speed. This is in a good agreement with Lewthwaite et al which found increase in skin friction drag of about $80 \%$ over the two year period [7], or $40 \%$ per year. Kind of vessel for their study was the 23 m fleet tender Royal Maritime Auxiliary Service (RMAS) LAMLASH. An increase in skin friction drag of about $32 \%$ per year for biofouling spread evenly at WSA.

The effect of an additional drag can retard the speed [7], [1], increases fuel consumption [2]. Therefore, the action to be taken by the ownership is by doing annual surveys of BKI appropriate recommendations.

\section{CONCLUSION}

In this work, physical models are used for investigating the roughness effect for ship. After the evaluation resistance can be concluded that a variation of the conditions of hull ship effect on the total drag. The total resistance vessels increased to $37 \%$ per year for biofouling spread evenly at WSA and $47 \%$ per year for biofouling spread not evenly at WSA. The results show that an increase in skin friction due to marine fouling about $41 \%$ per year. This is in a good agreement with Lewthwaite et al which found increase in skin friction drag of about $40 \%$ per year.

\section{ACKNOWLEDGEMENTS}

The first author would like to express his gratitude to the Ministry of Research, Technology and Higher Education of the Republic Indonesia which funding the research under a scheme called Pra S2-S2 Saintek Scholarships.

\section{REFERENCES}

[1] M. E. Curtin, "Trying to Solve the Biofouling Problem," Nat. Biotechnol., vol. 3, p. 38, 1985.

[2] M. A. Champ, "A review of organotin regulatory strategies, pending actions, related costs and benefits," Sci. Total Environ., 2000.

[3] A. I. Raiklin, Marine Biofouling Colonization Processes and Defenses. CRC Press Inc., 2005.

[4] L. Prandtl and H. Schlichting, "Das Widerstandsgesetz rauher Platten," Springer, pp. 649-662, 1934.

[5] L. D. Chambers, K. R. Stokes, F. C. Wood, and J. R. Walsh, "Modern approaches to marine antifouling coatings," 2006.

[6] S. A. Harvald, Resistance and Propulsion of Ships. New York: Wiley \& Sons, 1983.

[7] J. C. Lewthwaite, A. F. Molland, and K. W. Thomas, "An investigation into the variation of ship skin frictional resistance with fouling," 1985.

[8] M. Candries, "Drag, boundary-layer and roughness characteristics of marine surfaces coated with antifoulings," Newcastle University, 2001 .

[9] S. V. Hansen, "Performance monitoring of ships," Technical University of Denmark, 2011.

[10]M. P. Schultz, J. A. Bendick, E. R. Holm, and W. M. Hertel, "Economic impact of biofouling on a naval surface ship," Biofouling J. Bioadhesion Biofilm, pp. 87-98, 2011.

[11]A. F. Molland, S. R. Turnock, and D. A. Hudson, Ship Resistance and Propulsion: Practical Estimation of Propulsive Power. Cambridge University Press, 2011.

[12]ITTC, "Hull roughness," in Report of the ITTC Performance Committee, 1990. 


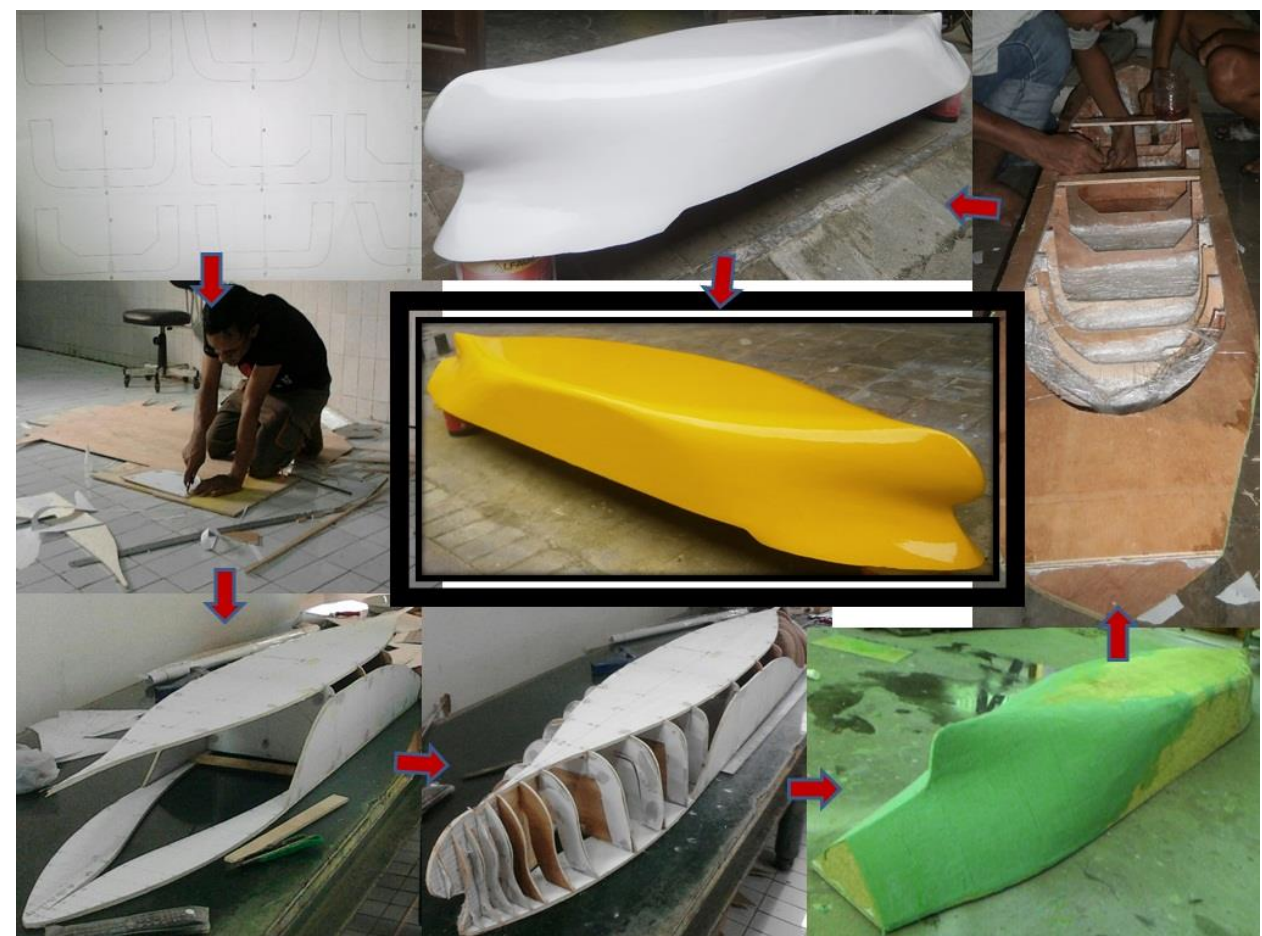

Figure 1. Steps of physical modelling

TABLE 1.

ROUGHNESS OF BIOFOULING

\begin{tabular}{lccc}
\hline & Bow & Amidships & Stern \\
\hline Port (m) & 0.015 & 0.016 & 0.023 \\
Starboard (m) & 0.015 & 0.016 & 0.023 \\
Flat bottom (m) & 0.015 & 0.018 & 0.020 \\
\hline \hline
\end{tabular}
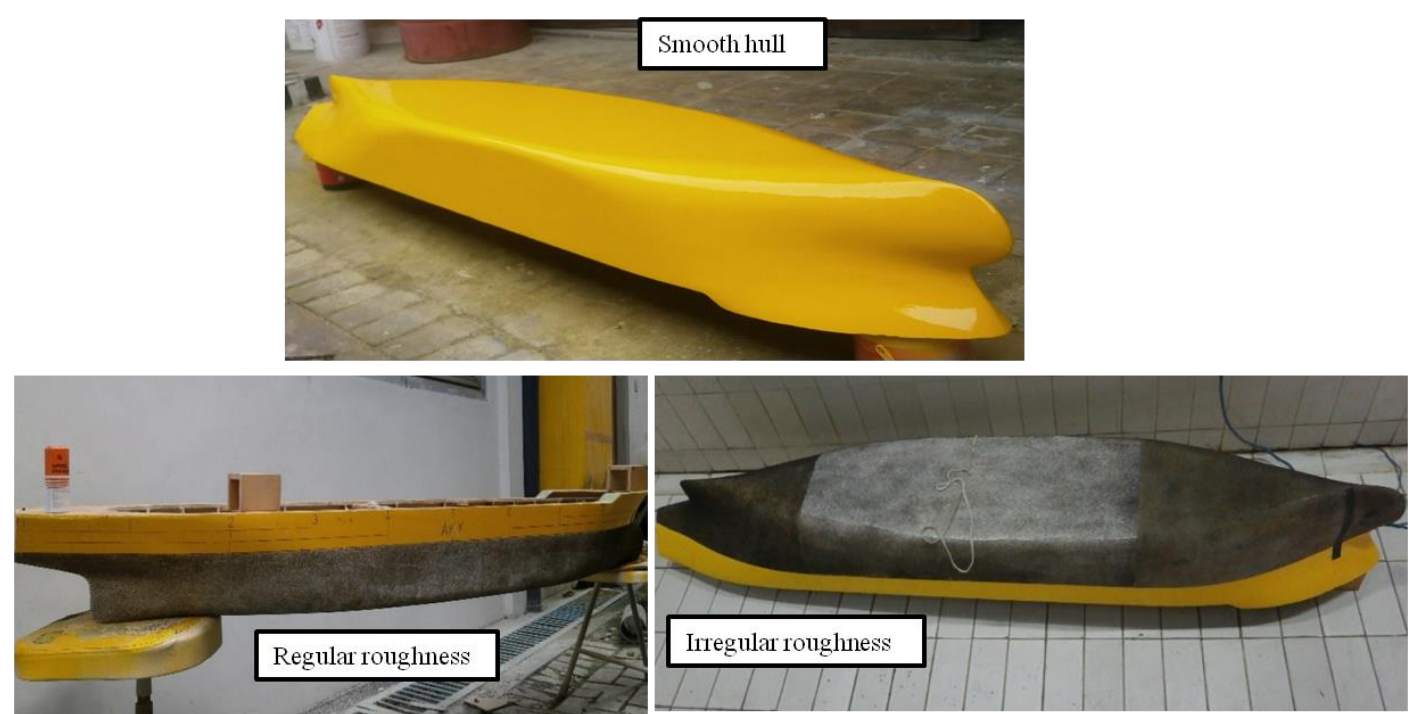

Figure 2. Model test with three condition hull surface 
TABLE 2.

ROUGHNESS SAND GRAIN DIAMETER SIZE FOR IRREGULAR ROUGHNESS MODEL

\begin{tabular}{lccc}
\hline \hline & Bow & amidships & Stern \\
\hline Port $\left(\times 10^{-3} \mathrm{~m}\right)$ & 0.015 & 0.016 & 0.023 \\
Starboard $\left(\mathrm{x} 10^{-3} \mathrm{~m}\right)$ & 0.015 & 0.016 & 0.023 \\
Flat bottom $\left(\mathrm{x} 10^{-3} \mathrm{~m}\right)$ & 0.015 & 0.018 & 0.020 \\
\hline \hline
\end{tabular}

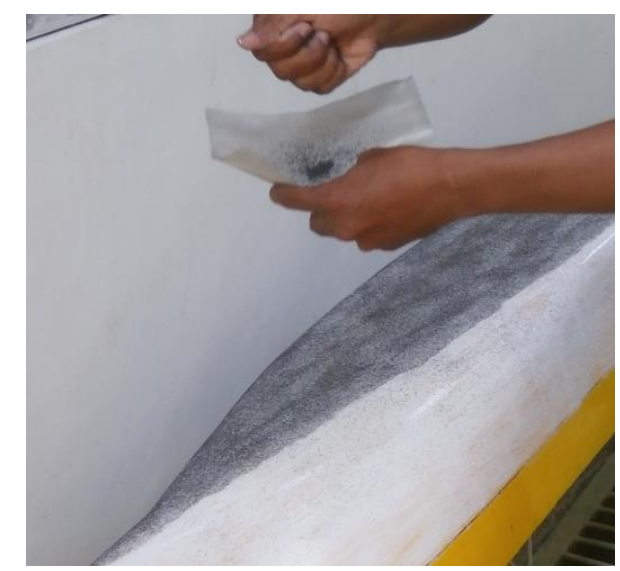

Figure 3. Sticking of sand with wire mesh

TABLE 3.

PARTICULAR OF SHIP

\begin{tabular}{ccc}
\hline \hline LOA $=109 \mathrm{~m}$ & LPP $=101 \mathrm{~m}$ & LWL $=106.07 \mathrm{~m}$ \\
$\mathrm{~B}=17.8 \mathrm{~m}$ & $\mathrm{H}=10 \mathrm{~m}$ & $\mathrm{~T}=7 \mathrm{~m}$ \\
$\nabla=9816.7 \mathrm{~m}^{3}$ & $\mathrm{WSA}=2646.8 \mathrm{~m}^{2}$ & $\mathrm{Vs}=14 \mathrm{knots}$ \\
\hline \hline
\end{tabular}

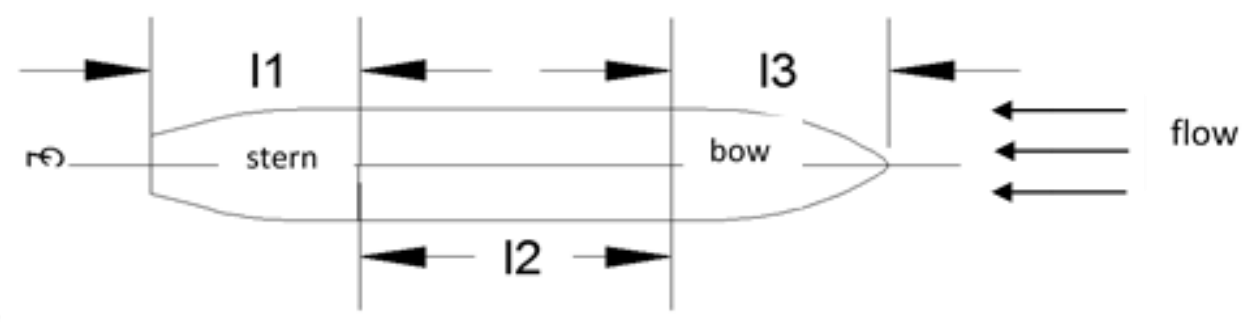

Figure 4. Classification of area with different roughness for irregular roughness model where: $11=0.571 \mathrm{~m}, 12=0.857 \mathrm{~m}$, and $13=0.597 \mathrm{~m}$

TABLE 4.

TOTAL RESISTANCE OF SHIP

\begin{tabular}{ccccc}
\hline \hline & & \multicolumn{3}{c}{ Total resistance $(\mathrm{kN})$} \\
\cline { 3 - 5 } Speed (knot) & Fn & Smooth hull & Regular roughness & Irregular roughness \\
\cline { 3 - 5 } 10 & 0.16 & 112.91 & 157.47 & 212.236 \\
12 & 0.20 & 161.00 & 247.30 & 266.810 \\
14 & 0.23 & 243.95 & 333.37 & 358.876 \\
16 & 0.26 & 361.90 & 454.98 & 531.804 \\
18 & 0.29 & 399.56 & 573.24 & 700.941 \\
\hline \hline
\end{tabular}




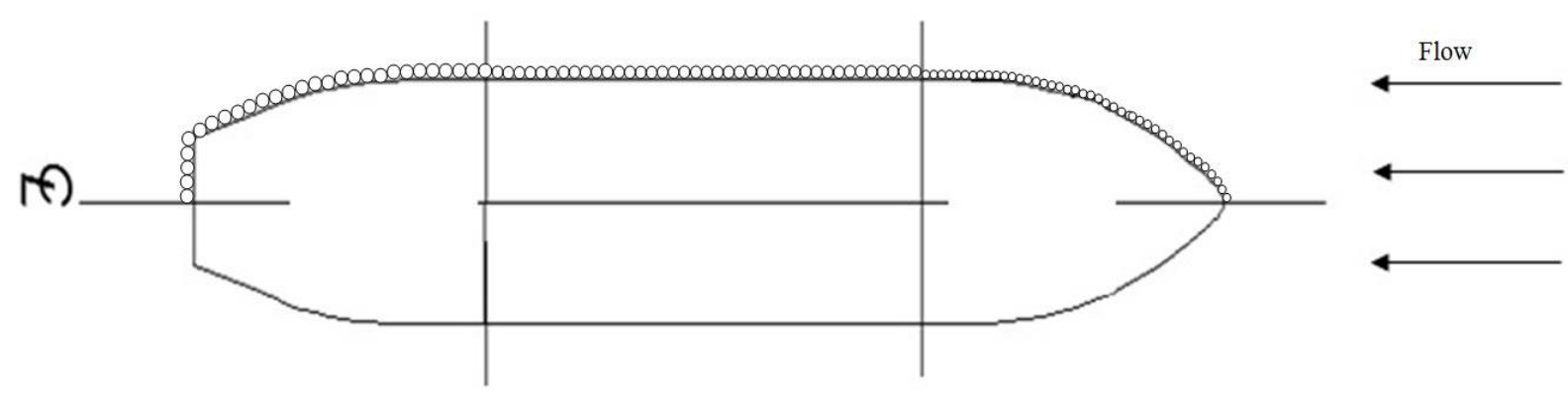

Figure 5. Cross section of sand grains stick to the model of irregular roughness

TABLE 5.

COMPARISON OF $\mathrm{C}_{\mathrm{F}}$ VALUE

\begin{tabular}{|c|c|c|c|c|c|}
\hline \multirow{2}{*}{$\mathrm{Fr}$} & \multicolumn{3}{|c|}{ Experiment } & \multicolumn{2}{|c|}{ Empirical formula } \\
\hline & Smooth $\left(\times 10^{-3}\right)$ & Regular $\left(\times 10^{-3}\right)$ & Irregular $\left(\mathrm{x} 10^{-3}\right)$ & Regular $\left(\times 10^{-3}\right)$ & Irregular $\left(\mathrm{x} 10^{-3}\right)$ \\
\hline 0.16 & 4.257 & 5.502 & 6.101 & 5.583 & 5.61 \\
\hline 0.20 & 4.101 & 5.775 & 6.153 & 5.583 & 5.61 \\
\hline 0.23 & 3.975 & 5.250 & 5.613 & 5.583 & 5.61 \\
\hline 0.26 & 3.871 & 4.887 & 5.725 & 5.583 & 5.61 \\
\hline 0.29 & 3.783 & 5.280 & 6.381 & 5.583 & 5.61 \\
\hline
\end{tabular}

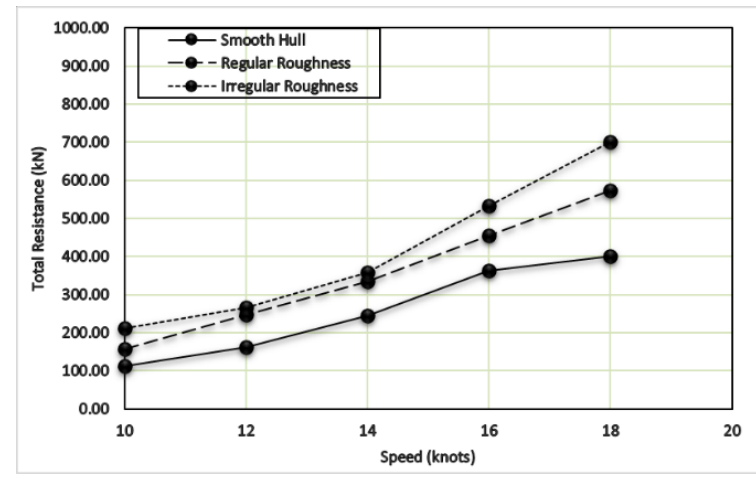

Figure 6. Total resistance of ship 